\title{
The Economic Consequences of Marital Dissolution for Women in the Middle Years ${ }^{1}$
}

\author{
Mary Corcoran \\ Institute for Social Research, University of Michigan
}

This article uses longitudinal data from the Panel Study of Income Dynamics to explore how changes in marital status affect the economic status of married women in their middle years. Results demonstrate that when a marriage ends, the economic status of women declines considerably. Components of income change are discussed, with emphasis on the extent to which women can compensate for the loss of a spouse's income through increases in paid labor, by changes in living arrangements, and by the use of public and private transfers.

Divorce is becoming increasingly common. Glick and Norton (1974; Norton \& Glick, 1976) estimate that $30 \%$ to $40 \%$ of marriages contracted by women born between 1940 and 1944 will end in divorce, but only $12 \%$ of marriages contracted by women born between 1900 and 1904 have ended in divorce. The rising divorce rate is offset by an increase in average longevity and hence by a decline in the number of marriages terminated by death each year (Bane, 1976a; Ross \& Sawhill, 1976). This means that the rate of marital disruption has been fairly constant for the last half-century, but the causes of marital disruption have changed considerably.

When a woman loses her husband, whether by divorce, separation or death, she is likely to simultaneously experience a sharp drop in her standard of living. A number of studies indicate that divorced, widowed, and separated women typically enjoy a lower family income than do married women in the same age.

\footnotetext{
1 This paper was presented at the Conference on Women in Midlife Crises, Cornell University, Ithaca, New York, October 30, 1976. The author would like to thank Saul Hoffman, Priscilla Hildebrandt, and Beverly Harris for their assistance. Saul Hoffman helped to plan and structure the analyses. Priscrilla Hildebrandt gave advice on the computer programming and typed the final draft. Beverly Harris helped a great deal with the computer programming. An unknown reviewer provided valuable comments on the final manuscript.
} 
bracket (Bane, 1976b; Hoffman, 1977; Hoffman \& Holmes, 1976; Ross \& Sawhill, 1976).

Economic problems may be particularly severe for women in their middle years. Such women are less likely than younger women to remarry when a marriage ends (Bane, 1975) and may be ill prepared to fend for themselves in the working world - particularly if the former have chosen to invest in the family at the expense of paid work. In addition, being older and female in a world that values youth and maleness may further hamper the middle-aged woman's ability to compete in the labor market.

Past research on the economic correlates of marital dissolution is often limited to cross-sectional data (Bernard, 1966; Cutright, 1971; Goode, 1956, 1962). Such data allow us to estimate the absolute differences in women's family income by marital status at a single point in time. Since the probability of divorce is negatively related to family income (see Bane, 1975; Cutright, 1971; Goode, 1956; Hoffman \& Holmes, 1976; Ross \& Sawhill, 1976), such analyses may overstate the economic consequences of divorce. Most crosssectional data do not allow estimation of the changes in income experienced by women whose marriages dissolve. ${ }^{2}$ Even studies which use longitudinal data generally concentrate on effects of divorce for all women (Hoffman, 1977; Hoffman \& Holmes, 1976; Ross \& Sawhill, 1976). Since the probaility of divorce decreases with age, the effects of divorce on young women may dominate results. Finally, studies of marital dissolution often ignore effects of widowhood or do not consider widowhood separately from divorce and separation (Bane; 1975, 1976b; Goode, 1956, 1962; Hoffman, 1977; Hoffman \& Holmes, 1976; Ross \& Sawhill, 1976). Yet, as we will see, death of a spouse is an important cause of marital dissolution among older women, and the economic consequences of widowhood differ somewhat from those of divorce.

I will examine changes in marital and economic status experienced between 1967 and 1975 by a national sample of 1,050 married women aged 35 to 54 years in 1968. This group is a subsample of the Panel Study of Income Dynamics (PSID). The PSID is a longitudinal survey of over 5,000 families which began in 1968; most families have been interviewed annually since then. The PSID deliberately oversampled Blacks and poor families. My subsample of 1,050 women include all women who were married in 1968 and who were still in the study in 1975. About $30 \%$ of the wives in this subsample were non-White. This article asks five questions:

1. What is the probability that a marriage will end by divorce, separation, or death between 1968 and 1975? What proportion of women whose marriages dissolve will remarry during this period?

${ }^{2}$ Of course, women divorced, separated, or widowed for various lengths of time could be asked to report retrospectively on their family standard of living when married and now. Unless reporting error in retrospective reports of family income is serious, such crosssectional data might well provide reasonable estimates of the reductions in standards of living following marital dissolution. 
2. What are the economic costs to women when their marriage dissolves?

3. How well does paid work substitute for the loss of a husband's income?

4. Does the ability to compensate for the loss of a spouse's income by paid labor diminish with age?

5. How well do other available support options (alimony, welfare, pensions, others' income) substitute for the economic losses incurred when a marriage ends?

\section{FINDINGS}

By $1975,12.2 \%$ of the women aged 35 to 54 in 1968 were no longer married to their original spouse. Of these $12.2 \%$, less than one-fifth had remarried by 1975 , so that $9.9 \%$ of the original sample of married women were still unmarried in 1975. The rates and causes of marital dissolution varied both with race and with age (see Table I). Non-Whites were more likely than Whites to become divorced or widowed between 1968 and 1975 (16.4\% versus 11.7\%). Among women aged 35 to 44 in 1967, divorce and separation accounted for over two-thirds of all dissolved marriages; but for women 45 to 54 , death of a spouse accounted for about three-quarters of all dissolved marriages. This pattern held within the racial subgroups as well.

Regardless of the cause of marital dissolution, when a marriage ended the economic consequences for the women were severe. Table II reports the percentage changes in real family income and in income/needs for women by marital status in 1975. Both these measures are adjusted for inflation. It may be useful to digress a moment to explain the income/needs measure. This is a ratio of real

Table I. Rates of Marital Dissolution $a$

\begin{tabular}{lrcc}
\hline \multicolumn{3}{c}{ Age } & \multicolumn{3}{c}{$\begin{array}{c}\text { Percent } \\
\text { separated } \\
\text { or divorced }\end{array}$} & $\begin{array}{c}\text { Percent } \\
\text { widowed }\end{array}$ \\
\hline 35 to 54 years & & & \\
$\quad$ Whites & 724 & 5.8 & 5.9 \\
$\quad$ Non-Whites & 304 & 6.5 & 9.9 \\
$\quad$ All & 1028 & 5.9 & 6.3 \\
35 to 44 years & & & \\
$\quad$ Whites & 423 & 7.6 & 2.3 \\
$\quad$ Non-Whites & 192 & 7.1 & 6.1 \\
$\quad$ All & 615 & 7.5 & 2.7 \\
$\quad$ 45 to 54 years & & & \\
$\quad$ Whites & 301 & 3.4 & 10.8 \\
$\quad$ Non-Whites & 112 & 6.0 & 15.7 \\
$\quad$ All & 413 & 3.6 & 11.3 \\
\hline
\end{tabular}

$a$ Weighted data were used to calculate rates. 
Table II. Change in Economic Well-Being ${ }^{a}$

\begin{tabular}{|c|c|c|c|}
\hline & $N$ & $\begin{array}{l}\text { Percent change } \\
\text { in real family } \\
\text { income }\end{array}$ & $\begin{array}{l}\text { Percent change } \\
\text { in income/needs }\end{array}$ \\
\hline \multicolumn{4}{|l|}{ All } \\
\hline Married throughout & 913 & 17.1 & 45.2 \\
\hline Divorced and not remarried $b$ & 56 & -43.6 & -18.0 \\
\hline Widowed and not remarried $b$ & 59 & -39.8 & -11.8 \\
\hline \multicolumn{4}{|l|}{ White } \\
\hline Married throughout & 657 & 16.8 & 43.4 \\
\hline Divorced and not remarried & 28 & -43.6 & -17.9 \\
\hline Widowed and not remarried & 39 & -43.3 & -13.7 \\
\hline \multicolumn{4}{|l|}{ Non-White } \\
\hline Married throughout & 256 & 20.8 & 83.5 \\
\hline Divorced and not remarried & 28 & -44.1 & -20.6 \\
\hline Widowed and not remarried & 20 & -13.3 & 4.4 \\
\hline
\end{tabular}

family income to annual family needs. The annual family needs measure is based on the Department of Agriculture's "Low-Cost Food Budget" and takes into account the number, ages, and sex of family members.

Changes in income vary dramatically with changes in marital status. Continuously married women do well by any standpoint. Real money income increases by about $17 \%$. At the same time, children are leaving home so that the needs standard drops and the ratio of income to family needs rises dramatical. ly (over $45 \%$ ). On the average, during the middle years, families enjoy a period of increased prosperity and decreased financial burdens. In the middle years familial investment by both husband and wife appears to pay off.

Divorced and widowed women did not fare so well between 1967 and 1974. Their real money income dropped by $40 \%$ and their income to needs ratio dropped by more than $10 \%$. Wives lost economically in two ways when their marriages ended. They did not participate in the income gains experienced by continuously married women, and their 1974 real money income was substantially lower than their 1967 real money income.

Clearly, marital status had no trivial effects on women's family income between 1967 and 1974. These net changes in total family income can be broken into two components: (1) the loss of a spouse's income and of assets that result when a marriage ends; (2) the extent to which alternate income sources compensate for these losses.

Women whose marriages end have three sources of alternate income. Women who are not employed can go to work, and employed women can in- 


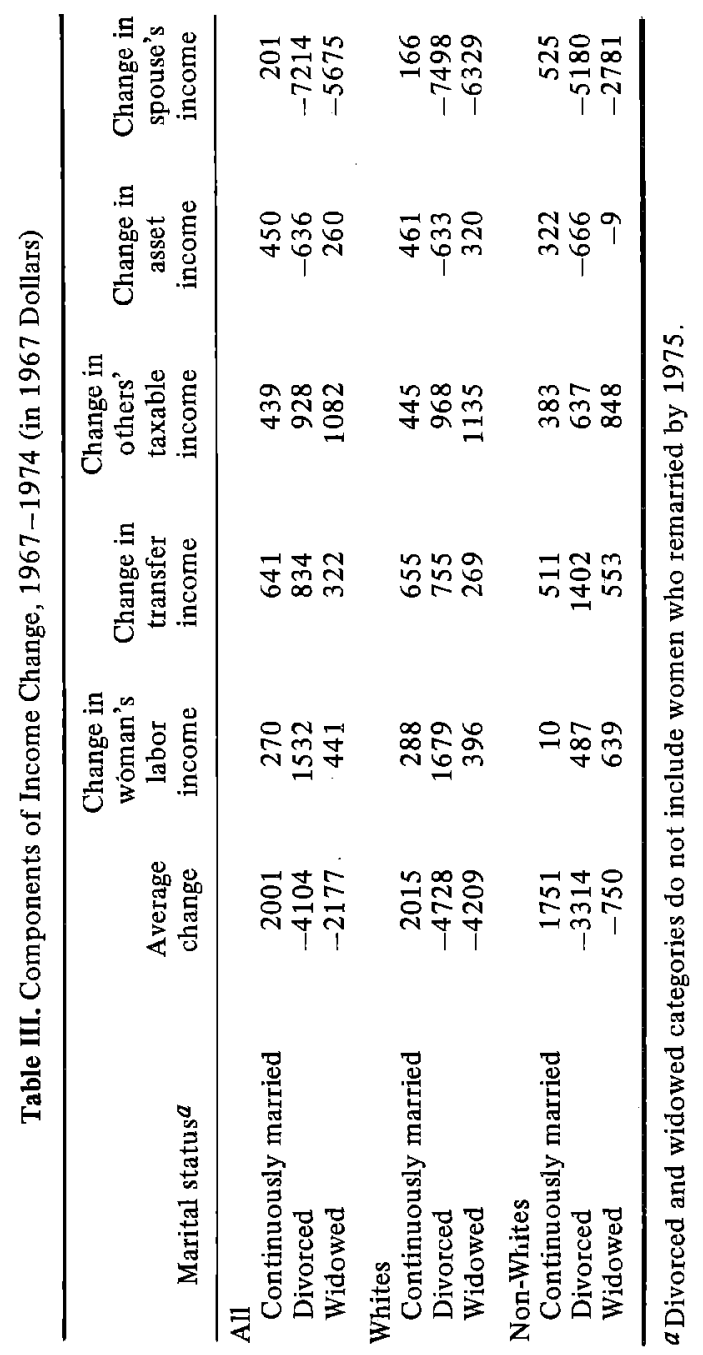


crease their paid work. Women can make use of various kinds of transfer income (alimony, welfare, retirement plans). Other household members may increase their contributions to family income. For instance, a widow might move in with a sister who works and shares expenses.

Table III breaks down the income changes experienced between 1967 and 1974 into five components by race and marital status. Between 1967 and 1974 , divorced women lost an average $\$ 7,200$ in spouse's income, while widowed women lost an average of $\$ 5,700$ in spouse's income. In addition, divorced women also lost about $\$ 636$ in asset income. This is likely caused by the division of family assets when a couple divorces. Widows' asset income actually increased from 1967 to 1974 , probably because widows inherit family assets.

Divorced women were able to recoup about $42 \%$ of the loss in spouse's income and in asset income by increasing paid labor, transfer income, and the income of others in the household. For White women, paid labor income was a major factor in replacing a spouse's income; non-White women relied more on transfer income. This may reflect race differences in work participation patterns. Non-White married women have higher work participation rates than White married women. This constrains the extent to which an increase in paid labor following divorce can supplement family income. For instance, if all non-White women were employed full time prior to their divorces, increases in paid labor would have virtually no effect on family income following their divorces.

Widows were able to replace about $62 \%$ of the loss in spouse's income, mostly through increases in the income contributions of other household members. Changes in labor income and nontransfer income were fairly small for widows. This is likely an age effect. Widows' average labor income should remain fairly constant between 1967 and 1974 for the simple reason that widows are, on the average, older than divorcées in this sample. More than three-fourths of the widows in this sample were in the 45- to 54-year-old group in 1967; women in this group may find it difficult to embark upon a new career when their husband dies. The relatively older age of widows may explain the low change in transfer income between 1967 and 1974. Since a large proportion of widows were 45 to 54 in 1967, many of their husbands were probably drawing retirement benefits in 1967. If women take over a husband's retirement plan at his death, this will not appear as an increase in transfer income.

Women lose substantially when a marriage ends. Not only do they no longer share a spouse's income but they are only able to make up $40 \%$ to $60 \%$ of this loss through additional earnings, transfer income, or contributions of other household members.

Marital dissolution affects the composition, as well as the level of 1974 income. Table IV decomposes total 1974 family income into taxable income, transfer income, and others' income. Taxable income is the primary component of 1974 income for continuously married women both White and non-White. This was not true for widows and divorcées. In 1974, taxable income was only 
Table IV. Composition of 1974 Income

\begin{tabular}{lcccc}
\hline & \multicolumn{4}{c}{ Composition (percent) } \\
\cline { 2 - 5 } & $\begin{array}{c}\text { Taxable } \\
\text { income } \\
\text { of woman } \\
\text { and spouse }\end{array}$ & $\begin{array}{c}\text { Transfer } \\
\text { income } \\
\text { of woman } \\
\text { and spouse }\end{array}$ & $\begin{array}{c}\text { Income of } \\
\text { others }\end{array}$ & $\begin{array}{c}\text { Total income } \\
\text { (1974 dollars) }\end{array}$ \\
\hline $\begin{array}{c}\text { All } \\
\text { Continuously married }\end{array}$ & 85.5 & 4.3 & 10.2 & 20,136 \\
$\begin{array}{c}\text { Divorced and still } \\
\text { unmarried }\end{array}$ & 50.3 & 18.4 & 31.4 & 8,687 \\
$\begin{array}{l}\text { Widowed and still } \\
\text { unmarried }\end{array}$ & 55.6 & 25.2 & 19.3 & 7,942 \\
$\begin{array}{c}\text { Whites } \\
\text { Continuously married }\end{array}$ & 85.7 & 4.1 & 10.2 & 20,656 \\
$\begin{array}{c}\text { Divorced and still } \\
\text { unmarried }\end{array}$ & 51.7 & 17.6 & 30.7 & 9,036 \\
$\begin{array}{l}\text { Widowed and still } \\
\text { unmarried }\end{array}$ & 57.8 & 23.9 & 18.3 & 8,106 \\
$\begin{array}{c}\text { Non-Whites } \\
\text { Continuously married } \\
\text { Divorced and still } \\
\text { unmarried }\end{array}$ & 82.5 & 6.6 & 10.8 & 15,835 \\
$\quad \begin{array}{l}\text { Widowed and still } \\
\text { unmarried }\end{array}$ & 34.8 & 26.6 & 39.0 & 6,193 \\
\hline
\end{tabular}

slightly more than half of 1974 income for widows and divorcées. The rest of 1974 income was either transfer income or the income of others in the family unit. Transfer income was generally a more important component of widows' 1974 income than of divorcées' 1974 income. The contribution of other members of the family unit was more important for the latter.

Differences in income composition by marital status are more striking if we look at non-Whites. Taxable income accounted for less than $35 \%$ of 1974 income for non-White divorced women.

Women whose marriages dissolve experienced greater increases in average labor income between 1967 and 1974 than did women who remained married throughout this period. Table V reports women's employment status by age and by marital status in 1974. Age appears to condition the extent to which women are able to (or choose to) enter the labor force. Women who were 35 to 44 in 1967 were very likely to be working in 1974 if their marriage had ended. More than $65 \%$ of divorced and widowed women who were not working in 1967 were working in 1976; only $40 \%$ of the continously married women in this age group had entered the labor force by 1974 if they were unemployed in 1967. Older women were unlikely to increase their supply of labor between 1967 and 1974 , no matter what their marital status. 
Table V. Women's Employment Status $a$

\begin{tabular}{lrrrrc}
\hline & & & & & $\begin{array}{c}\text { Probability of } \\
\text { Peing employed } \\
\text { employed } \\
\text { in 1974 if not } \\
\text { employed } \\
\text { in 1967 }\end{array}$ \\
\hline 35 to 44 years & $N$ & 1967 & 1974 & & \\
$\quad$ Continuously married & 556 & 46.1 & 57.2 & 40.6 \\
$\quad$ Divorced and not remarried & 43 & 55.5 & 67.9 & 65.4 \\
$\quad$ Widowed and not remarried & 16 & 49.0 & 74.4 & 67.8 \\
45 to 54 years & & & & \\
$\quad$ Continuously married & 357 & 51.3 & 45.1 & 15.4 \\
$\quad$ Divorced and not remarried & 13 & 58.9 & 42.1 & 22.1 \\
$\quad$ Widowed and not remarried & 43 & 52.8 & 46.8 & 12.5 \\
\hline
\end{tabular}

$a_{\text {This table was not broken down by race because of a small sample size. }}$

In theory, at least, society provides some supports for the women in her middle years whose marriage suddenly ends. Divorced women supposedly have access to alimony and welfare, while widowed women are supported by pensions, retirement plans, and Social Security benefits. But the actual benefits received from supports such as alimony appear to be much smaller than is commonly believed (see Weitzman, 1974).

Table VI reports the coverage and extent of welfare, alimony and child care, and retirement benefits by marital status and race. Divorced women's major sources of transfer income are alimony and child care and welfare, while widows' major source of transfer income is retirement benefits. Nonetheless, about $55 \%$ of all divorced women received neither welfare nor alimony and child care payments, while about $38 \%$ of all widows received no retirement benefits. Even when individuals received support, the annual level of support was low. The average welfare payment was $\$ 2,150$; the average alimony and child care payment was $\$ 1,930$; and the average retirement benefit was $\$ 2,860$.

\section{CONCLUSIONS AND IMPLICATIONS FOR FUTURE RESEARCH}

This article finds that women's economic well-being is considerably affected by changes in marital status during their middle years. The real family incomes of women who remained married from 1967 to 1974 rose on the average by $17 \%$, while real incomes declined more than $40 \%$ for women who were either divorced, separated, or widowed in 1974. This large decline occurred despite the fact that women whose marriages ended supplemented their reduced income by increasing paid labor and transfer income and by relying more on the 


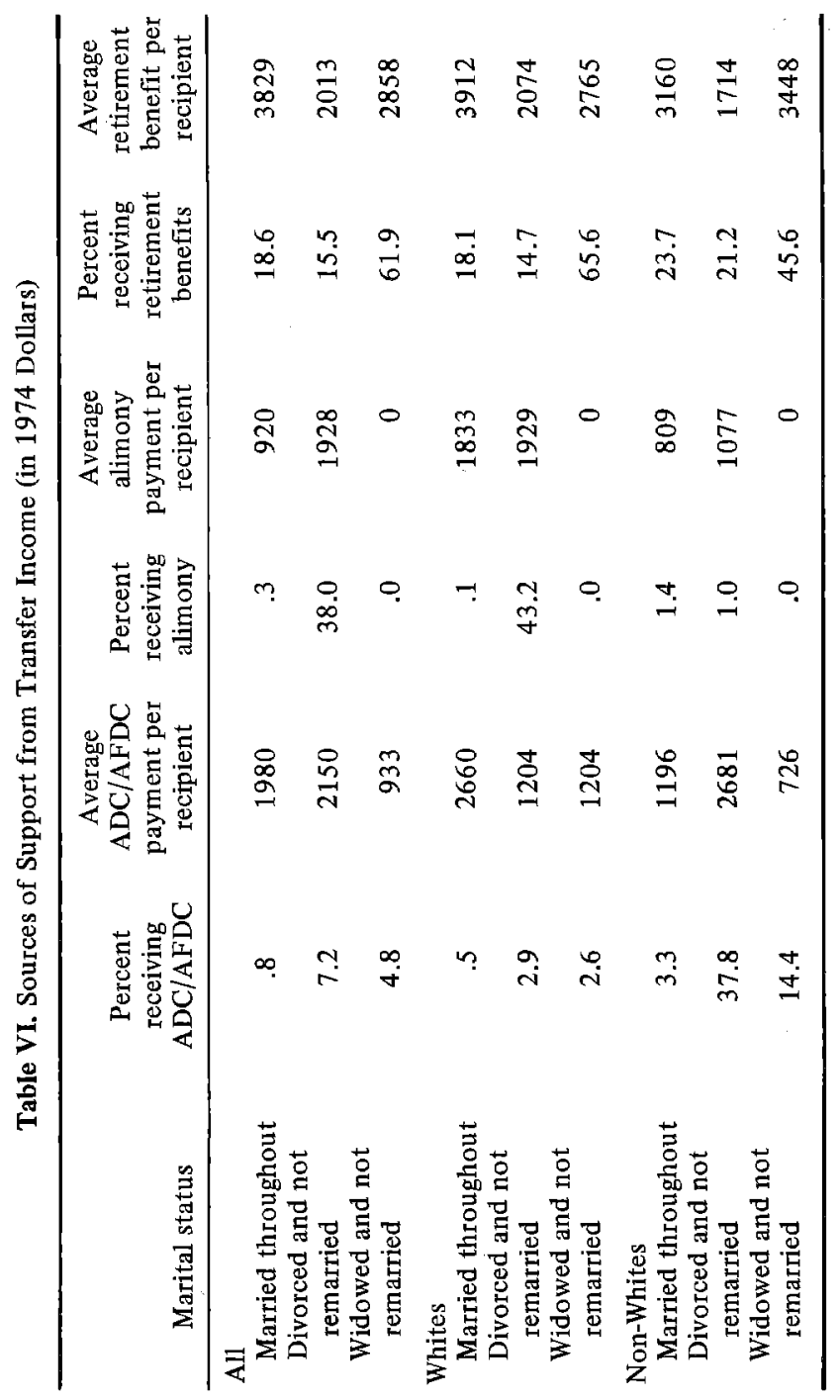


income of other household members. Second, women employed a variety of strategies to deal with the loss of a spouse's income. These strategies varied with age, race, and type of marital dissolution. Younger women (35 to 44 in 1967) increased paid labor, but this strategy was not used by older women ( 45 to 54 in 1967). Some women appeared to cope with family problems by moving in with relatives or friends. Widows and divorcées were each more likely to live in a multiple earner household than were continuously married women. About two out of five divorced or separated women received some alimony and/or welfare. Generally Whites received alimony and non-Whites received welfare. It appears that welfare may serve non-Whites as a crude substitute for alimony and child support payments. About $60 \%$ of all widows received some retirement benefits. Third, traditional supports such as welfare, alimony, and retirement plans inadequately compensated women for income losses incurred when a marriage ends.

Marital dissolution poses substantial economic problems for women in their middle years, and the economic alternatives available to such women do not appear to adquately meet these problems. This analysis merely defines the problem. Future research should explore in more depth how women cope with the economic consequences of marital dissolution. For instance, available economic alternatives may vary considerably depending on one's education, one's employment status, the number of children still at home, and/or geographic location. Certain kinds of community and/or familial supports may be critical in helping women to compensate for the income losses which accompany marriage's end. A better understanding of the processes by which women cope (or fail to cope) with the economic consequences of marital dissolution is crucial if we are to plan and implement policies to improve the economic status of divorced, separated, and widowed women in their middle years.

\section{REFERENCES}

Bane, M. J. Economic influence on divorce and remarriage. Unpublished working paper. Cambridge, Mass.: Center for the Study of Public Policy, 1975.

Bane, M. J. Here to stay: American families in the twentieth century. New York: Basic Books, 1976. (a)

Bane, M. J. Marital distuption and the lives of children. Journal of Social Issues, 1976, 32, 103-117. (b)

Bernard, J. Marital stability and patterns of status variables. Journal of Marriage and the Family, 1966, 28, 421-429.

Cutright, P. Income and family events: Marital stability. Journal of Marriage and the Family, $1971,33,291-300$.

Glick, P. C., \& Norton, A. J. Perspectives on the recent upturn in divorce and remarriage. Demography, 1974, 10, 301-314.

Goode, W. J. Women in divorce. New York: Free Press, 1956.

Goode, W. J. Marital satisfaction and instability: A cross-cultural analysis of divorce rates. International Social Science Journal, 1962, 14, 507-526. 
Hoffman, S. Marital instability and the economic status of women. Demography, 1977, $13,67-76$.

Hoffman, S., \& Holmes, J. Husbands, wives and divorce. In G. A. Duncan \& J. N. Morgan (Eds.), Five thousand American families (Vol. 4). Ann Arbor: Institute for Social Research, University of Michigan, 1976.

Norton, A. J., \& Glick, P. Marital instability: Past, present and future. Journal of Social Issues, 1976, 32, 5-20.

Ross, H., \& Sawhill, J. Time of transition: The growth of families headed by women. Washington, D.C.: The Urban Institute, 1976.

Wejtzman, L. J. Legal regulation of marriage and divorce. California Law Review, 1974, 62(4). 